\title{
Algoritma Genetika dengan Mutasi Terbatas untuk Penjadwalan Perkuliahan
}

\author{
Sisferi Hikmawan ${ }^{1, *}$, Windu Gata ${ }^{1}$ \\ ${ }^{1}$ Program Studi IImu Komputer; STMIK Nusa Mandiri; JI. Damai No.8, Warung Jati Barat \\ (Margasatwa), Jakarta Selatan, Telp.(021) 78839513 Fax.(021) 78839421; e-mail: \\ gansisferi@gmail.com, windu@nusamandiri.ac.id \\ * Korespondensi: e-mail: gansisferi@gmail.com
}

Submitted: 26/02/2021; Revised: 08/03/2021; Accepted: 11/05/2021; Published: 27/05/2021

\begin{abstract}
In University, lecture scheduling is the most important factor in service satisfaction for students. UNISMA Bekasi still uses the manual method in scheduling lectures. Genetic Algorithms can solve scheduling with different constraints. In the proposed Genetic Algorithm, the mutation operator is changed to be a limited individual mutation and a selection feature that is adjusted to the constraints in the problem to be solved. And Genetic Algorithms with limited mutations are proven to have advantages in accommodating the constraints found in UNISMA Bekasi. The result of testing in experiments conducted on curriculum data for the Odd Semester of the Academic Year 2020/2021 using a Genetic Algorithm with mutation_individu_terbatas, namely minimum load $=0$ with iterations $=10$ and population $=500$.
\end{abstract}

Keywords: Data Mining, Genetic Algorithm, Schedule, Mutation

\begin{abstract}
Abstrak
Dalam perkuliahan, penjadwalan perkuliahan merupakan faktor paling penting dalam kepuasan pelayanan terhadap mahasiswa. UNISMA Bekasi masih menggunakan cara manual dalam penjadwalan perkuliahan. Algoritma Genetika dapat memecahkan penjadwalan dengan constraint berbeda-beda. Pada Algoritma Genetika yang diajukan, dilakukan pengubahan operator mutasi menjadi mutasi individu terbatas dan fitur seleksi yang disesuaikan dengan constraint dalam permasalahan yang ingin dipecahkan. Dan Algoritma Genetika dengan mutasi terbatas terbukti memiliki kelebihan dalam mengakomodir permasalahan constraint yang terdapat di UNISMA Bekasi. Dihasilkan Pengujian dalam percobaan yang dilakukan terhadap data kurikulum untuk Semester Ganjil Tahun Akademik 2020/2021 dengan menggunakan Algoritma Genetika dengan mutasi_individu_terbatas yaitu beban minimum = 0 dengan iterasi $=10$ dengan populasi $=500$.
\end{abstract}

Kata kunci: Data Mining, Algoritma Genetika, Mutasi, Jadwal Perkuliahan

\section{Pendahuluan}

Salah satu proses akademik adalah Penjadwalan Perkuliahan. Penjadwalan merupakan tindakan yang berkaitan dengan mengalokasikan sumberdaya yang dibutuhkan dengan rentang waktu tertentu (Pinedo, 2008). Di Fakultas Teknik UNISMA Bekasi, sesuai Surat Keputusan Rektor memiliki kewenangan menentukan penjadwalan dan tetap berkoordinasi dengan DAPA selaku sentral pelayanan mahasiswa.Terjadi banyak revisi terkait jadwal dikarenakan setiap Fakultas masih menggunakan metode manual untuk pembuatan jadwal perkuliahan. 
Salah satu permasalahan dalam penjadwalan adalah bentrok ruangan, dosen dan mahasiswa. Tidak hanya bentrok, namun salah satu kepuasan bagi mahasiswa dalam hal jadwal adalah meminimalkan pergerakan mahasiswa dalam berpindah ruangan kelas. Dan inilah yang disebut sebagai constraint atau batasan(Pinedo, 2008) (Shiau, 2011).

Algoritma genetika telah digunakan sebagai solusi dalam menyelesaikan permasalahan penjadwalan, karena dapat menghasilkan jadwal yang hampir optimal (Ahmad et al., 2012). Algoritma genetika juga telah digunakan dalam penjadwalan yang lebih khusus yaitu jadwal perkuliahan (Myori \& Hastuti, 2019) (Abdelhalim \& El Khayat, 2016).

Menurut Qashlim dan Assidiq (Qashlim \& Assiddiq, 2016) Constraint dalam penjadwalan perkuliahan terbagi menjadi dua, yaitu soft constraint dan hard constraint. Pembagian tersebut untuk membedakan dimana hard constraint (batasan yang sulit) merupakan batasan yang harus di ambil saat bertumbukkan dengan soft constraint (batasan yang lunak) (Shiau, 2011). Dalam hal ini, kepuasan pengguna menjadi salah satu optimalisasi dalam proses permodelan algoritma genetika.

Penelitian terkait tentang fungsi objektif dalam penjadwalan masih diperbincangkan (Zhang et al., 2020). Metode yang ditawarkan untuk algoritma ini salah satunya dengan menekankan pada fitur mutasi, seleksi dan juga dalam fitness function.

Penelitian ini bertujuan untuk menganalisa algoritma genetika untuk penjadwalan perkuliahan di Fakultas Teknik UNISMA Bekasi dalam menyelesaikan permasalahan constraint pada Fakultas tersebut menggunakan kombinasi mutasi terbatas dan seleksi.

\section{Metode Penelitian}

\subsection{Pengumpulan Data}

Sumber data yang digunakan menggunakan dataset dari Universitas Islam 45 Bekasi, dalam hal ini data akan diambil dari Sistem Informasi Akademik (SIMAK) UNISMA Bekasi dengan menggunakan akun Staff Pengelola Akademik.

Tabel 1. Contoh Data Dosen Pengampu Matakuliah

\begin{tabular}{cclll}
\hline No & Kode & \multicolumn{1}{c}{ Nama } & NIK & Perkuliahan \\
& & & \\
\hline $\mathbf{1}$ & TKS1621001 & $\begin{array}{l}\text { Menggambar } \\
\text { Bangunan Sipil }\end{array}$ & 45101061998124 & REG_A \\
& & & \\
\hline $\mathbf{2}$ & TKS1621002 & Kalkulus & 45104052015009 & REG_A \\
\hline $\mathbf{3}$ & TKS1621003 & Fisika Mekanika & 45404012016004 & REG_A \\
\hline $\mathbf{4}$ & TKS1621004 & $\begin{array}{l}\text { Statistika dan } \\
\text { Probabilitas }\end{array}$ & 45101101994014 & REG_A \\
\hline $\mathbf{5}$ & TKS1621005 & Statika Statis & 45104032015004 & \\
& & Rertentu-T & & \\
\hline
\end{tabular}

Sumber: Hasil Penelitian (2021)

Pengambilan data kurikulum di SIMAK UNISMA Bekasi setelah didapatkan hasilnya adalah seperti pada tabel berikut: 
Tabel 2. Contoh Data Dosen Pengampu Matakuliah

\begin{tabular}{|c|c|c|c|c|c|c|c|}
\hline No & $\begin{array}{c}\text { Kode } \\
\text { Matakuliah }\end{array}$ & $\begin{array}{c}\text { Nama } \\
\text { Matakuliah }\end{array}$ & $\begin{array}{c}\text { Model } \\
\text { Pembelajaran }\end{array}$ & $\begin{array}{c}\text { Kode } \\
\text { Semester }\end{array}$ & Kategori & $\begin{array}{c}\text { Penyeleng } \\
\text { gara }\end{array}$ & sks \\
\hline 1 & $\begin{array}{c}\text { TKS2102/T } \\
\text { KS162100 } \\
2\end{array}$ & Kalkulus & Tatap Muka & 1 & $\begin{array}{c}\text { MK } \\
\text { Program } \\
\text { Studi }\end{array}$ & $\begin{array}{l}\text { Program } \\
\text { Studi }\end{array}$ & 3 \\
\hline 2 & $\begin{array}{c}\text { TKS2103/T } \\
\text { KS162100 } \\
3\end{array}$ & Fisika Mekanika & Tatap Muka & 1 & $\begin{array}{c}\text { MK } \\
\text { Program } \\
\text { Studi }\end{array}$ & $\begin{array}{c}\text { Program } \\
\text { Studi }\end{array}$ & 2 \\
\hline 3 & $\begin{array}{c}\text { TKS2104/T } \\
\text { KS162100 } \\
4\end{array}$ & $\begin{array}{l}\text { Statistika dan } \\
\text { Probabilitas }\end{array}$ & Tatap Muka & 1 & $\begin{array}{c}\text { MK } \\
\text { Program } \\
\text { Studi }\end{array}$ & $\begin{array}{l}\text { Program } \\
\text { Studi }\end{array}$ & 2 \\
\hline 4 & $\begin{array}{c}\text { TKS2105/T } \\
\text { KS162100 } \\
5\end{array}$ & $\begin{array}{l}\text { Statika Statis } \\
\text { Tertentu-T }\end{array}$ & Tatap Muka & 1 & $\begin{array}{c}\text { MK } \\
\text { Program } \\
\text { Studi }\end{array}$ & $\begin{array}{l}\text { Program } \\
\text { Studi }\end{array}$ & 3 \\
\hline 5 & $\begin{array}{c}\text { TKS2106/T } \\
\text { KS162100 } \\
6\end{array}$ & $\begin{array}{l}\text { Pratikum Fisika } \\
\text { Mekanika }\end{array}$ & Praktikum & 1 & $\begin{array}{c}\text { MK } \\
\text { Program } \\
\text { Studi }\end{array}$ & $\begin{array}{l}\text { Program } \\
\text { Studi }\end{array}$ & 1 \\
\hline
\end{tabular}

Sumber: Hasil Penelitian (2021)

\subsection{Pengolahan Data}

Tahap selanjutnya yaitu pengolahan data. Dalam pengolahan data, langkah yang dilakukan adalah dengan cara menghilangkan mata kuliah yang tidak membutuhkan penjadwalan seperti Skripsi dan Kuliah Kerja Nyata. Mata kuliah Skripsi dan Kuliah Kerja Nyata merupakan mata kuliah diluar dari jadwal dan biasanya penentuan waktu serta tanggalnya ditentukan oleh Fakultas.

\subsection{Inisialisasi dan Representasi Populasi Awal}

Pada algoritma genetika, pembangkitan populasi awal adalah langkah dimana dimunculkannya gen dengan kromosom secara acak untuk nantinya akan diseleksi sebagai orang tua. Untuk pembangkitan populasi awal tetap random namun dibatasi sesuai dengan Jenis Mata Kuliah dan Ruang Induk.

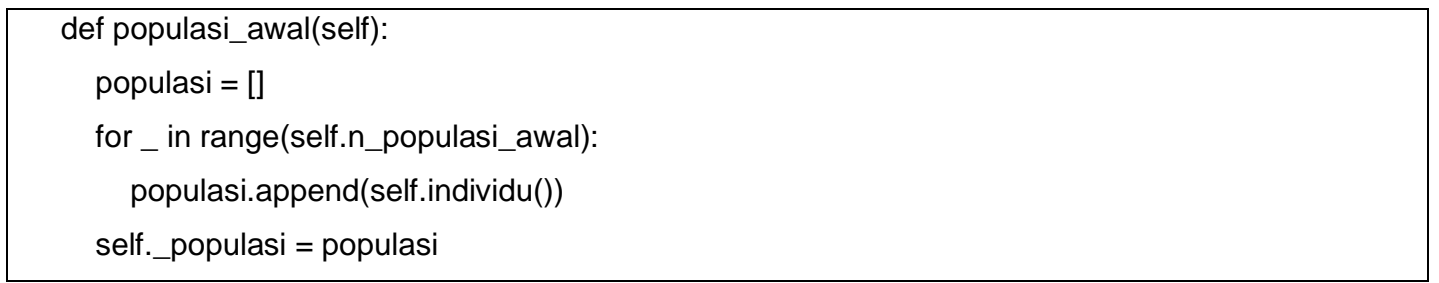

Dengan perintah di atas, populasi_awal menyimpan hasil fungsi individu () ke dalam array populasi [] dan dilakukan pengulangan sejumlah n_populasi_awal. N_populasi_awal 
adalah nilai untuk menentukan berapa jumlah populasi yang kita inginkan dalam Algroritma Genetika. Untuk isi dari fungsi individu () adalah sebagai berikut

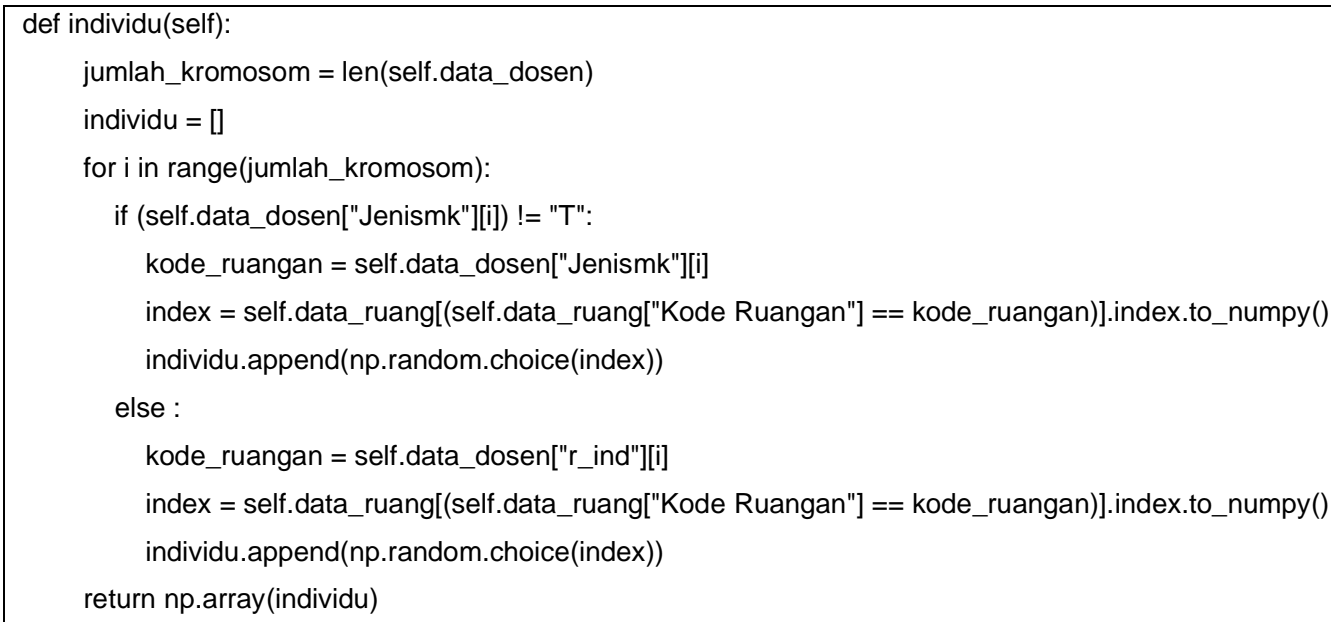

\subsection{Implementasi Algoritma Genetika}

Constraint di Fakultas Teknik UNISMA Bekasi terdiri dari hard constraints dan soft contraints. Hard constraints: a) Dalam satu plot waktu kuliah, Dosen hanya dapat mengajar satu kali; b) Setiap plot waktu perkuliahan hanya dapat diajarkan oleh satu Dosen; c) Mahasiswa hanya dapat menghadiri satu waktu perkulihan dalam satu plot waktu; d) Setiap ruang kelas hanya dapat digunakan satu perkuliahan pada waktu yang sama; e) Laboratorium komputer akan digunakan untuk jadwal matakuliah tertentu. Soft constraints: a) Dosen dan mahasiswa dapat memilih hari, jam dan ruang yang disukai berdasarkan plot waktu yang tersedia; b) Meminimalkan gerakan mahasiswa untuk melakukan perpindahan ruangan; c) Gerakan dosen untuk perpindahan jadwal hari, jam dan ruang.

Fitness dalam Algoritma Genetika menggunakan rumus (Hijriana, 2015) :

$$
\text { fitness }=\frac{1}{1+\text { Pinalti }}
$$

Dimana :

pinalti $=\sum$ Jumlah beban

Jumlah beban adalah akumulasi bobot dari pelanggaran terhadap setiap constraint. Dengan begitu jumlah beban adalah total pelanggaran yang terjadi dalam gen. Maka fitness terbaik adalah yang bernilai 1. Namun fitness tidak terbatas hanya menggunakan pembagian angka 1, dalam penelitian ini penulis menggunakan fungsi pembebanan.

Pembobotan dari pelanggaran terhadap constraint mengacu pada tabel seperti berikut:

Tabel 3. Constraint dan Beban

\begin{tabular}{clc} 
No. & \multicolumn{1}{c}{ Constraint } & $\begin{array}{c}\text { Beban } \\
\text { Pelanggaran }\end{array}$ \\
\hline C1 & $\begin{array}{l}\text { Dalam satu plot waktu kuliah, Dosen hanya dapat mengajar } \\
\text { satu kali }\end{array}$ & 1 \\
\hline C2 & $\begin{array}{l}\text { Mahasiswa hanya dapat menghadiri satu waktu perkulihan } \\
\text { dalam satu plot waktu }\end{array}$ & 1 \\
\hline
\end{tabular}




\begin{tabular}{clllc} 
No. & \multicolumn{2}{c}{ Constraint } & $\begin{array}{c}\text { Beban } \\
\text { Pelanggaran }\end{array}$ \\
\hline C3 & $\begin{array}{l}\text { Setiap ruang kelas hanya dapat digunakan satu perkuliahan } \\
\text { pada waktu yang sama }\end{array}$ & 1 \\
\hline C4 & $\begin{array}{l}\text { Laboratorium komputer } \\
\text { matakuliah tertentu }\end{array}$ & & & \\
\hline
\end{tabular}

Sumber: Hasil Penelitian (2021)

Dan dihasilkan persamaan fungsi untuk constraint beban adalah sebagai berikut:

$$
\begin{aligned}
& \sum C 1=\sum_{i=\text { duplikasi }}^{n} N I K_{i}, t_{i}, d_{i} \\
& \sum C 2=\sum_{i=\text { duplikasi }}^{n} k_{i}, t_{i}, d_{i} \\
& \sum C 3=\sum_{i=\text { duplikasi }}^{n} r_{i}, t_{i}, d_{i} \\
& \sum C 4=\sum_{i=}^{n} j r_{i} \neq r_{i}
\end{aligned}
$$

$\sum C 1=$ adalah total beban untuk pelanggaran $C 1$, dimana di hitung sejumlah $\mathrm{n}$ baris yang terdapat $\mathrm{NIK}=\mathrm{Id}$ dosen, $\mathrm{t}=$ plot waktu, dan $\mathrm{d}=$ =hari yang sama. Jika terjadi duplikasi setiap baris atau i adalah 1.

$\sum C 2=$ adalah total beban untuk pelanggaran $\mathrm{C} 2$, dimana di hitung sejumlah $\mathrm{n}$ baris yang terdapat $\mathrm{k}=$ Kode Kelas, $\mathrm{t}=$ plot waktu, dan $\mathrm{d}=$ hari yang sama, jika terjadi duplikasi setiap baris atau i adalah 1.

$\sum C 3=$ adalah total beban untuk pelanggaran $C 3$, dimana di hitung sejumlah $\mathrm{n}$ baris yang terdapat $r=$ Kode Ruangan, $t=$ plot waktu, dan $d=$ hari yang sama, jika terjadi duplikasi setiap baris atau i adalah 1 .

$\Sigma C 4=$ adalah total beban untuk pelanggaran $\mathrm{C} 4$, dimana di hitung apakah matakuliah Praktek sesuai dengan Kode Ruangan yang ditentukan untuk praktek. Jika berbeda maka setiap baris atau i yang berbeda adalah 1 .

Fitness menggunakan formula sebagai berikut:

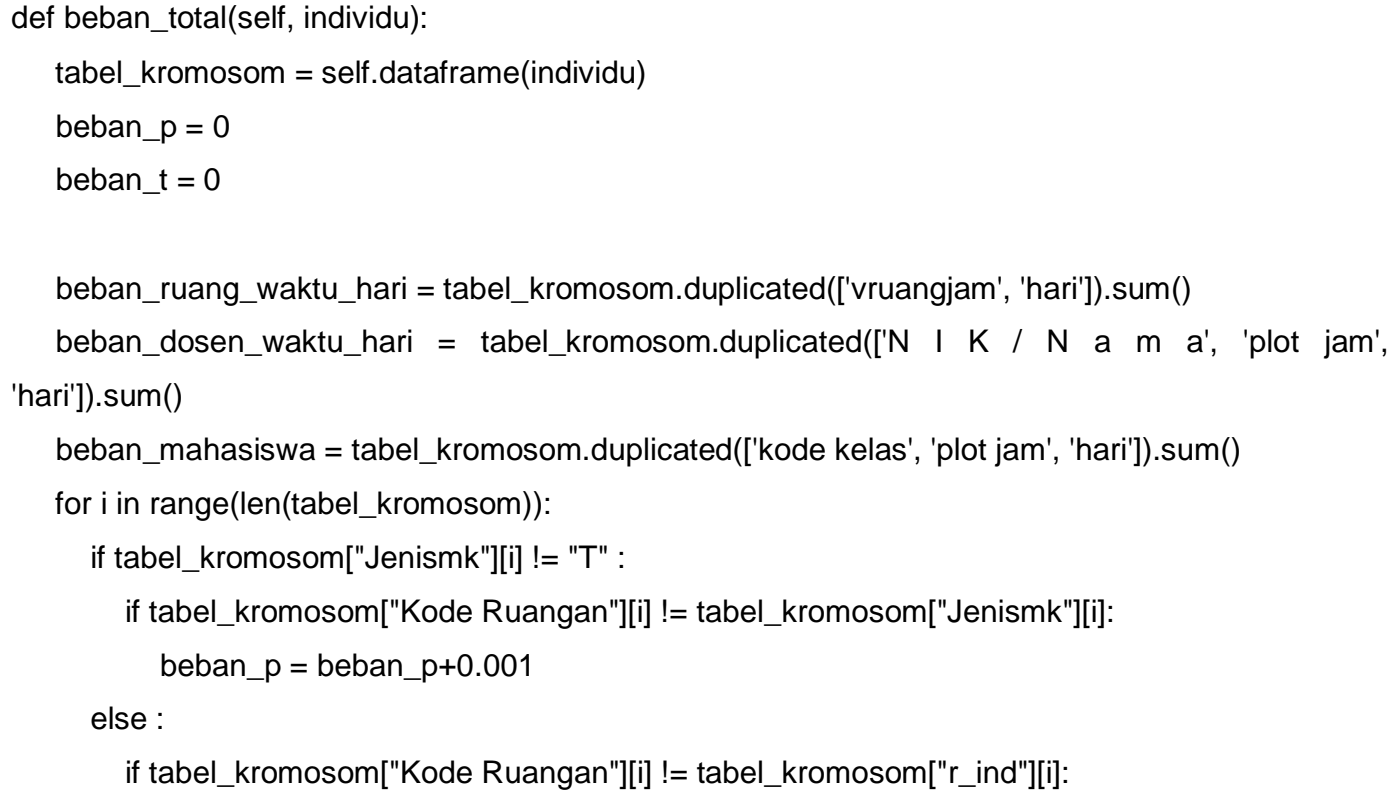




\section{beban_t $=$ beban_t+0.000001}

\#print(beban_t)

return beban_dosen_waktu_hari + beban_ruang_waktu_hari + beban_mahasiswa + beban_p + beban_t

Permodelan algoritma genetika standar menurut Pinedo (Pinedo, 2008) adalah sebagai berikut:

Langkah 1.

$K=1$

Bangkitkan populasi, dan dihasilkan $P=($ gen $1 \ldots n)$

Langkah 2.

Pilih 2 gen terbaik dari populasi gen, sebagai Parent yaitu genAyah $(K)$ dan genIbu $(K)$

Gandakan genAyah dan GenIbu menjadi genAnakl(K) dan GenAnak2(K)

Lakukan kawin silang

Lakukan mutasi

Langkah 3.

Set $P=(\operatorname{genAyah}(K), \operatorname{genIbu}(K), \operatorname{genAnak} 1(K), \operatorname{genAnak} 2(K))$

Jika $K=$ N maka STOP

Jika tidak lakukan langkah 2.

Permodelan algoritma genetika menggunakan optimalisasi Sequence-Dependent Setup

Times untuk mengatasi permasalahan constraint ruang berurutan menggunakan formula:

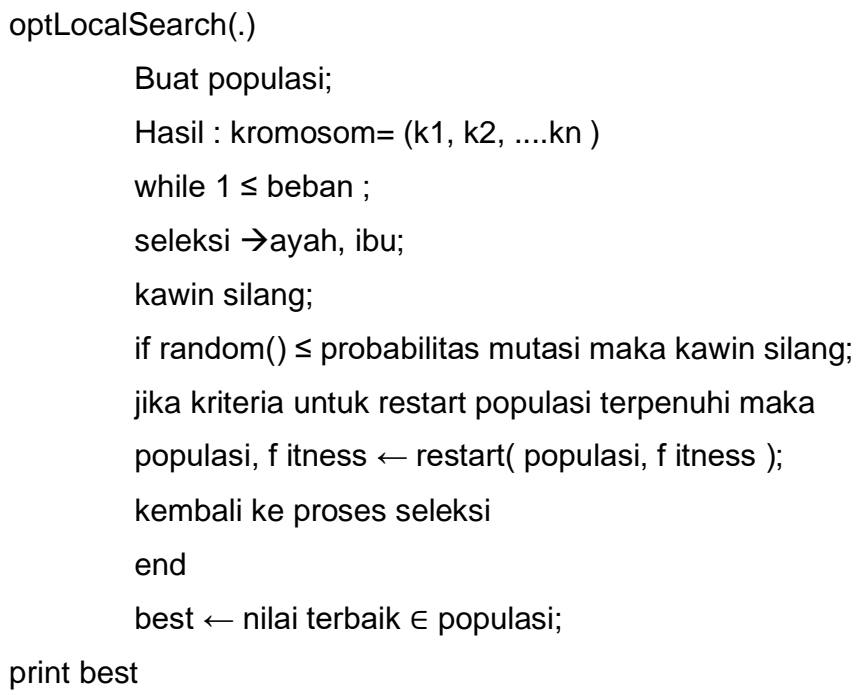

Dan dapat terlihat dari bagan seperti pada gambar berikut : 


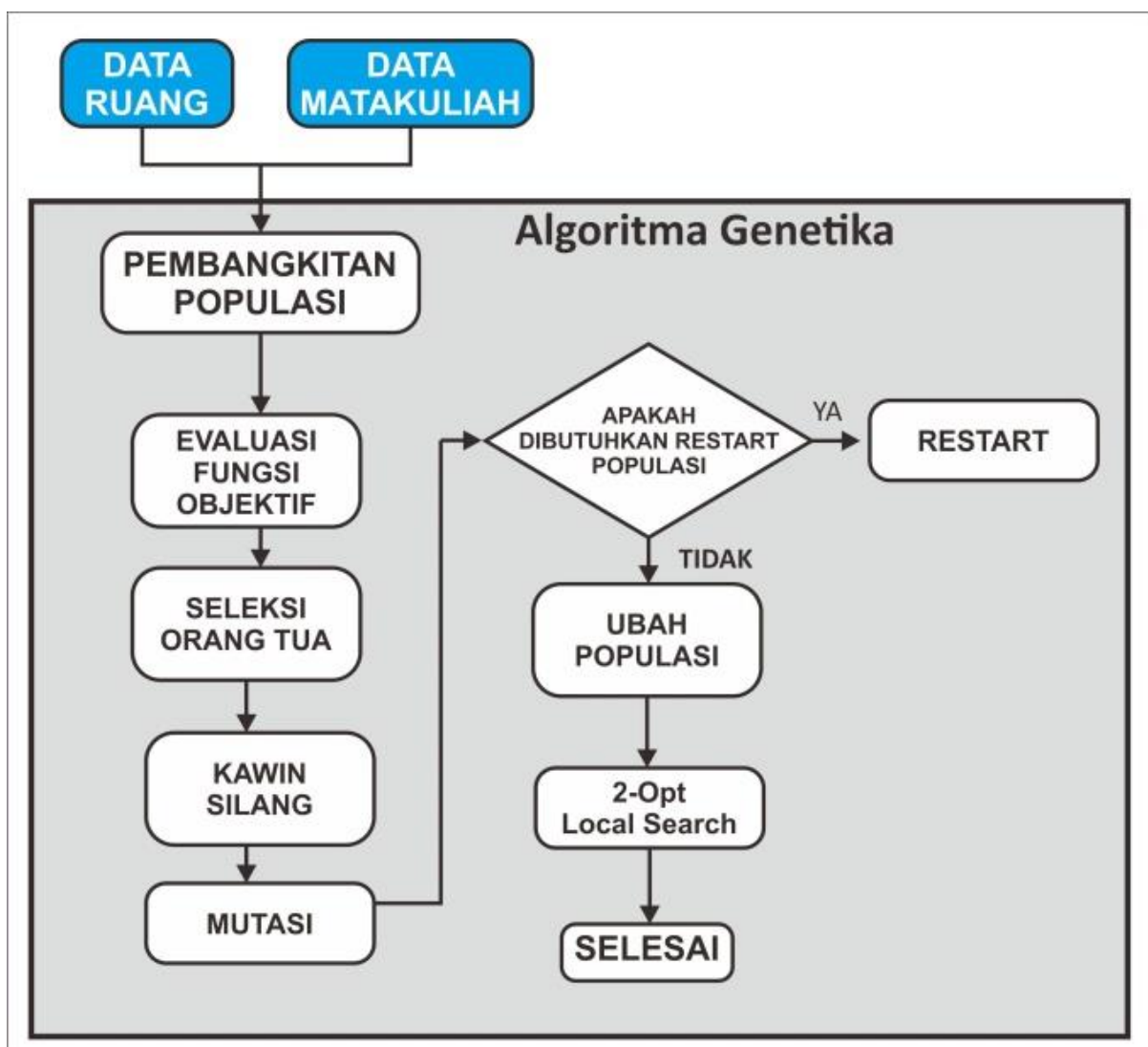

Sumber: Hasil Penelitian (2021)

Gambar 1. Bagan Alur Proses Algoritma Genetika Sequence-Dependent Setup Times

Sedangkan dalam permodelan Algoritma Genetika Mutasi Terbatas yang penulis ajukan adalah penyederhanaan fitur selection dan penentuan model mutasi yang digunakan. Serta untuk memungkinkan terjadinya seleksi gen yang dibutuhkan maka proses mutasi menggunakan formula seperti dibawah ini:

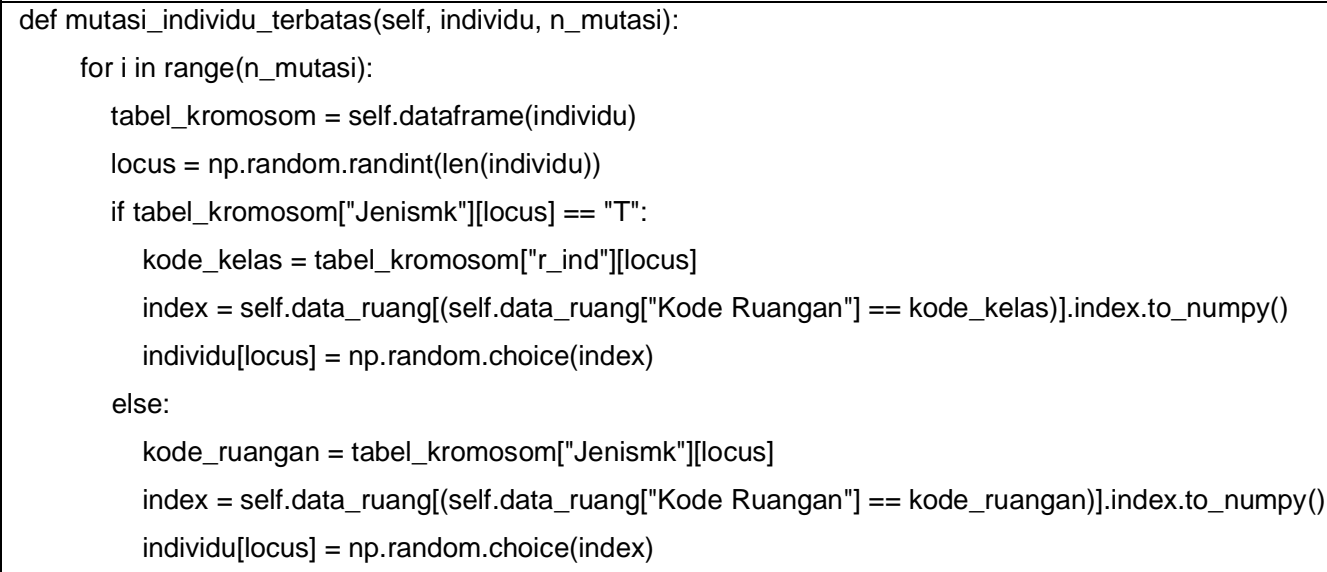

Dan dapat terlihat dari bagan seperti pada gambar berikut : 


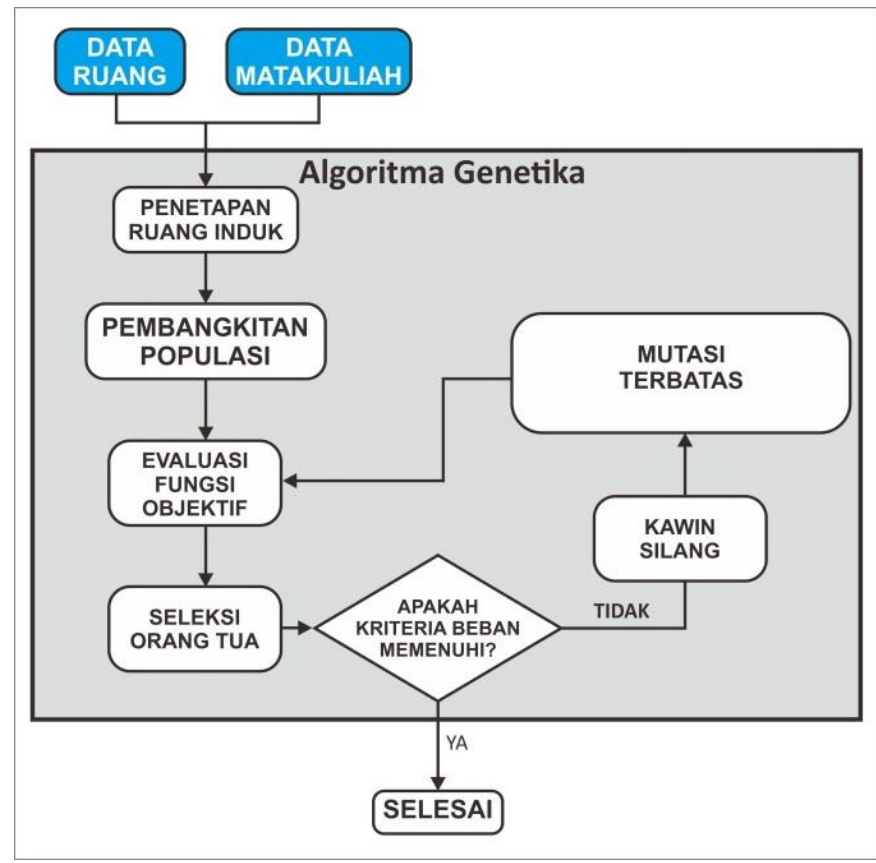

Sumber: Hasil Penelitian (2021)

Gambar 2. Bagan Alur Proses Algoritma Genetika menggunakan Mutasi Terbatas

\subsection{Evaluasi dan Validasi Hasil Penelitian}

Setelah tersimpan iterasi, beban atau fitness dan juga konvergensinya maka dilakukan evaluasi dan validasi dari algoritma genetika yang kami ajukan. Evaluasi adalah melihat hasil dengan fungsi objektif yaitu menghitung nilai fungsi apakah membaik atau memburuk, serta melihat konvergensi apakah terjadi penyimpangan atau sebaliknya.

\section{Hasil dan Pembahasan}

\subsection{Algoritma Genetika Pinedo}

Pengujian dengan menggunakan Algoritma Genetika standar, dihasilkan dalam iterasi ke 500 seperti pada gambar berikut:

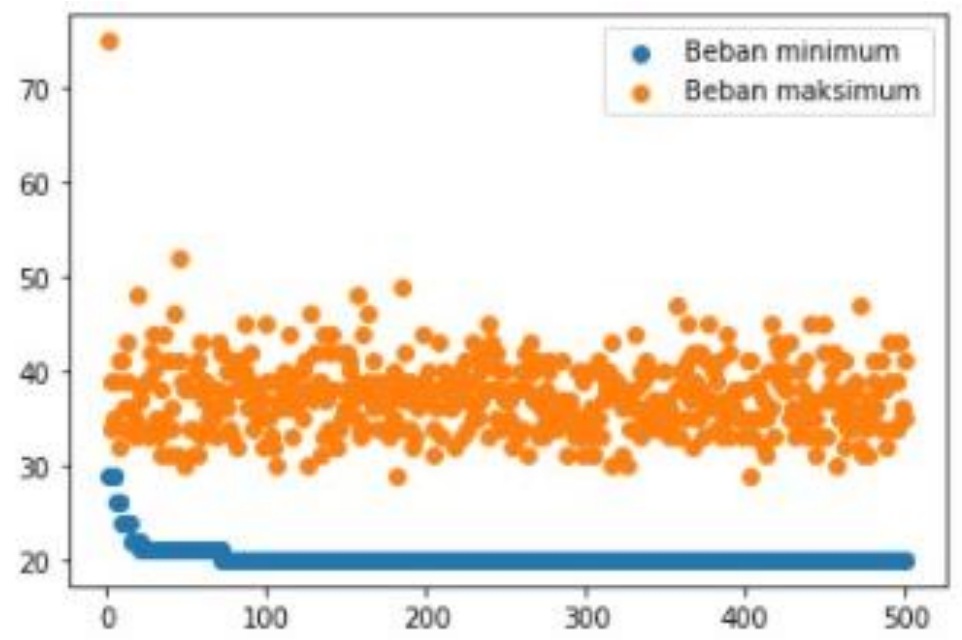

Sumber: Hasil Penelitian (2021)

Gambar 3. Scatter Plot GA Pinedo 


\subsection{Algoritma Genetika dengan Sequence-Dependent Setup Times}

Pada pengujian, Algoritma Genetika dengan optimalisasi menurut Levi R. Abreu ini dijalankan dengan menggunakan populasi sebesar 100, 200,300, dan 500. Pengujian ini dilakukan untuk mengetahui apakah sistem penjadwalan dengan metode Algoritma Genetika ini berjalan sesuai dengan tujuan yang diinginkan yaitu terpenuhinya semua batasan atau constraint yang sebelumnya telah ditetapkan dan perbedaan dari setiap jumlah populasi yang digunakan.

Untuk menggambarkan soft constraint "Meminimalkan gerakan mahasiswa untuk melakukan perpindahan ruangan". Jika ini dimasukkan kedalam fungsi maka akan bertabrakan dengan constraint C4. Untuk itulah mengapa diletakkan di soft constraint. Perhitungan nilai minimum pergerakan kelas adalah

$$
\text { Nilai minimum pergerakan kelas }=\frac{\sum K_{h, k r}}{\sum K} \times 100
$$

Artinya nilai $\sum K_{h, k r}$ adalah total kode kelas dengan hari dan kode ruangan yang sama dibagi dengan $\sum K$ yaitu total kode kelas dikali 100. Nilai ini untuk melihat hubungan jika mutasi terbatas diterapkan terhadap fungsi objektif terhadap soft constraint tersebut.

Berikut hasil dari Algoritma Genetika dengan n_keturunan $=100$

Tabel 5. Hasil Algoritma Genetika populasi $=100$

\begin{tabular}{ccc}
\hline $\mathrm{n} \_$populasi & $\begin{array}{c}\text { Beban }<1 \text { setelah } \\
\text { Iterasi ke: }\end{array}$ & $\begin{array}{c}\text { nilai minimum } \\
\text { pergerakan kelas }\end{array}$ \\
\hline 100 & 22 & $8 \%$
\end{tabular}

Sumber: Hasil Pengolahan Data (2021)

Pada Tabel 5 terlihat iterasi minimal yang dihasilkan adalah 22 dengan nilai minimum pergerakkan kelas sebesar $8 \%$. Untuk scatter plot yang terlihat pada Gambar 5.

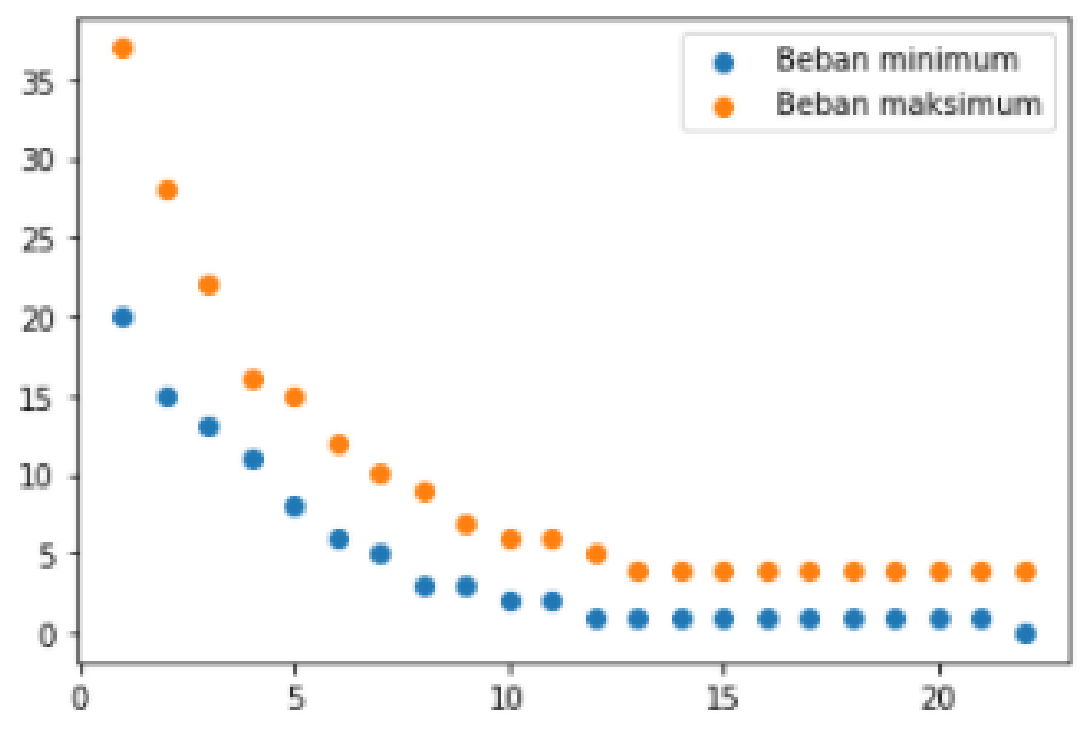

Sumber: Hasil Penelitian (2021)

Gambar 5. Scatter Plot GA Sequence-Dependent Setup Times populasi $=100$ 
Berikut hasil dari Algoritma Genetika dengan $n \_k e t u r u n a n=200$

Tabel 6. Hasil Algoritma Genetika populasi $=200$

\begin{tabular}{lll}
\hline n_populasi & $\begin{array}{l}\text { Beban }<1 \text { setelah } \\
\text { Iterasi ke: }\end{array}$ & $\begin{array}{l}\text { nilai } \\
\text { pergerakan kelas }\end{array}$ \\
\hline 200 & 12 & $19.5 \%$
\end{tabular}

Sumber: Hasil Pengolahan Data (2021)

Pada Tabel 6 terlihat iterasi minimal yang dihasilkan adalah 12 dengan nilai minimum pergerakkan kelas sebesar $19.5 \%$. Untuk scatter plot yang terlihat pada gambar berikut:

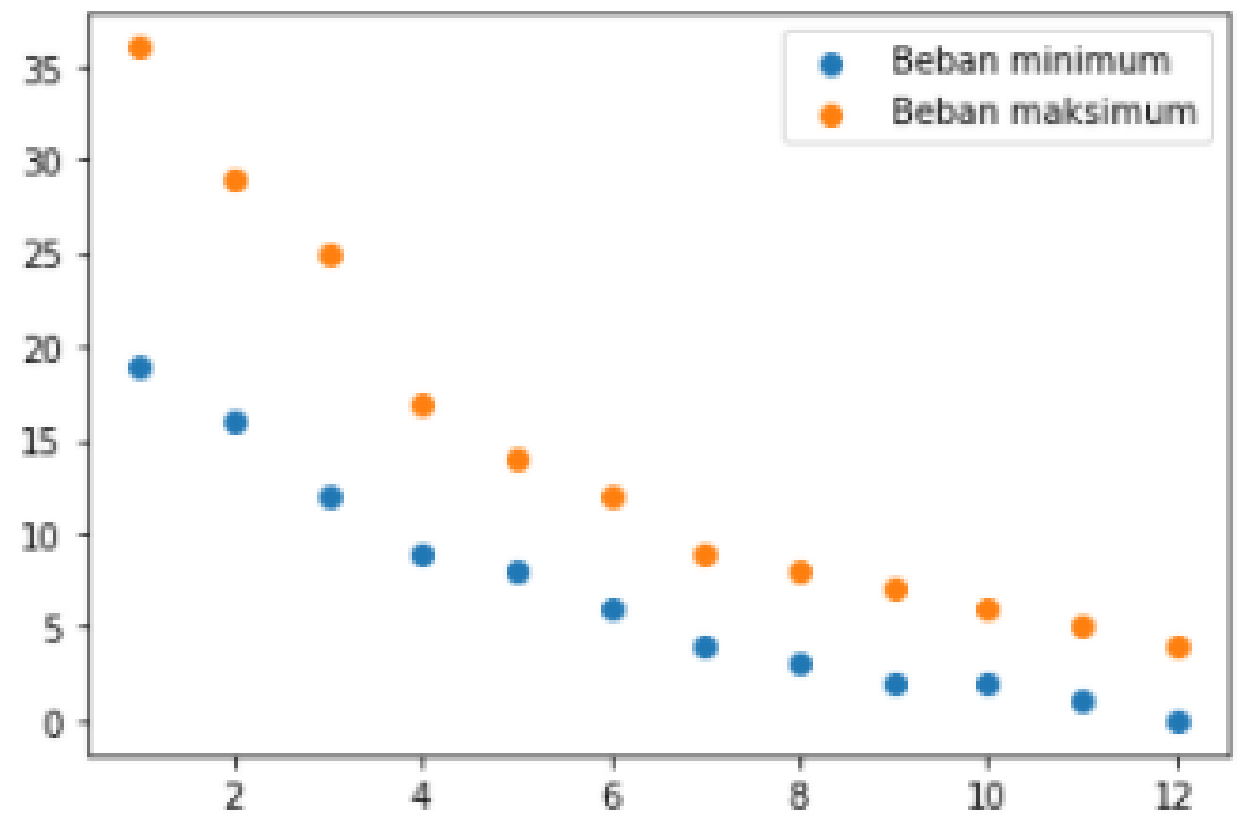

Sumber: Hasil Penelitian (2021)

Gambar 6. Scatter Plot GA Sequence-Dependent Setup Times populasi $=200$

Berikut hasil dari Algoritma Genetika dengan n_keturunan $=300$

Tabel 7. Hasil Algoritma Genetika Sequence-Dependent Setup Times populasi $=300$

\begin{tabular}{lll}
\hline n_populasi & $\begin{array}{l}\text { Beban }<1 \text { setelah } \\
\text { Iterasi ke: }\end{array}$ & $\begin{array}{l}\text { nilai } \\
\text { pergerakan kelas }\end{array}$ \\
\hline 300 & 9 & $14.6 \%$
\end{tabular}

Sumber: Hasil Penelitian (2021)

Pada Tabel 7 terlihat iterasi minimal yang dihasilkan adalah 9 dengan nilai minimum pergerakkan kelas sebesar $14.6 \%$. Untuk scatter plot yang terlihat pada Gambar berikut: 


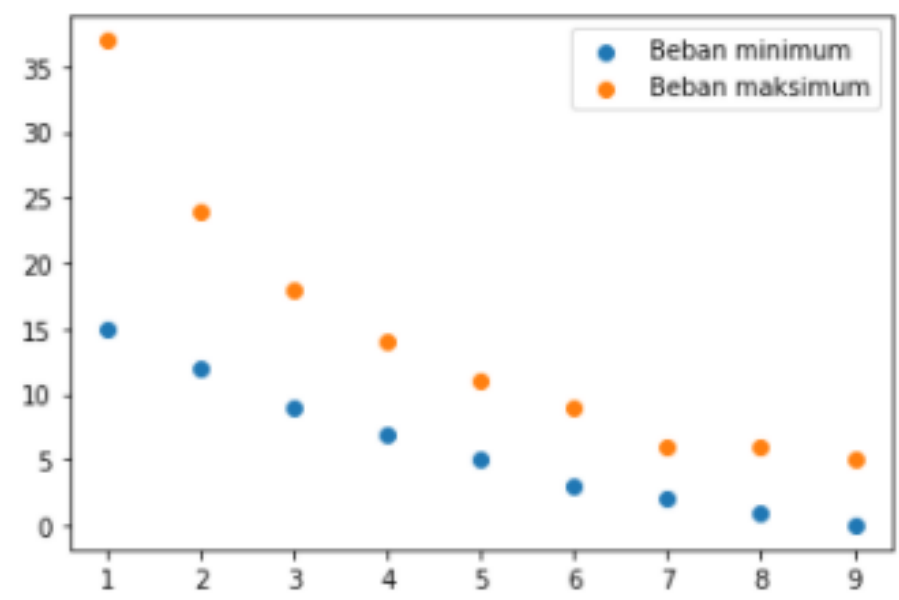

Sumber: Hasil Penelitian (2021)

Gambar 7. Scatter Plot GA Levi R. Abreu populasi $=300$

\subsection{Algoritma Genetika dengan Mutasi Terbatas}

Pada pengujian, Algoritma Genetika dengan mutasi terbatas ini dijalankan dengan menggunakan populasi sebesar 100, 200,300, dan 500. Pengujian ini untuk mengetahui apakah sistem penjadwalan dengan metode Algoritma Genetika mutasi terbatas ini berjalan sesuai dengan tujuan yang diinginkan yaitu terpenuhinya semua batasan atau constraint yang sebelumnya telah ditetapkan dan perbedaan dari setiap jumlah populasi yang digunakan.

Berikut hasil dari Algoritma Genetika dengan n_keturunan $=100$

Tabel 9. Hasil Algoritma Genetika dengan Mutasi Terbatas, populasi $=100$

\begin{tabular}{|c|c|c|}
\hline n_populasi & $\begin{array}{l}\text { Beban }=0 \text { setelah } \\
\text { Iterasi ke: }\end{array}$ & $\begin{array}{l}\text { nilai minimum } \\
\text { pergerakan kelas }\end{array}$ \\
\hline 100 & 12 & $20.3 \%$ \\
\hline
\end{tabular}

Sumber: Hasil Penelitian (2021)

Pada Tabel 9 terlihat iterasi minimal yang dihasilkan adalah 12 dengan nilai minimum pergerakkan kelas sebesar $20.3 \%$. Untuk scatter plot yang terlihat pada Gambar 9 terlihat sedikit terjadinya perubahan jarak beban maksimum dan minimum.

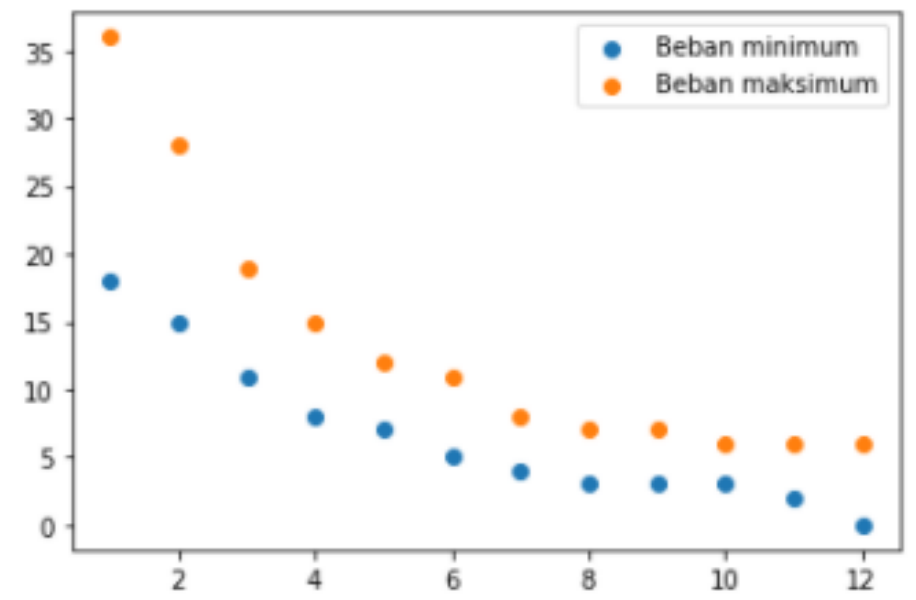

Sumber: Hasil Penelitian (2021)

Gambar 9. Scatter Plot GA Mutasi Terbatas Populasi $=100$ 
Setelah itu Algoritma Genetika dijalankan dengan keturunan $=200$. Dan dihasilkan yang terlihat pada Tabel 10 yaitu iterasi minimal yang didapatkan adalah 14 iterasi dengan nilai minimum pergerakan kelas adalah $6.6 \%$.

Tabel 10. Hasil Algoritma Genetika populasi $=200$

\begin{tabular}{lll}
\hline n_populasi & $\begin{array}{l}\text { Beban }=0 \text { setelah } \\
\text { Iterasi ke: }\end{array}$ & $\begin{array}{l}\text { nilai minimum } \\
\text { pergerakan kelas }\end{array}$ \\
\hline 200 & 14 & $6.6 \%$
\end{tabular}

Sumber: Hasil Penelitian (2021)

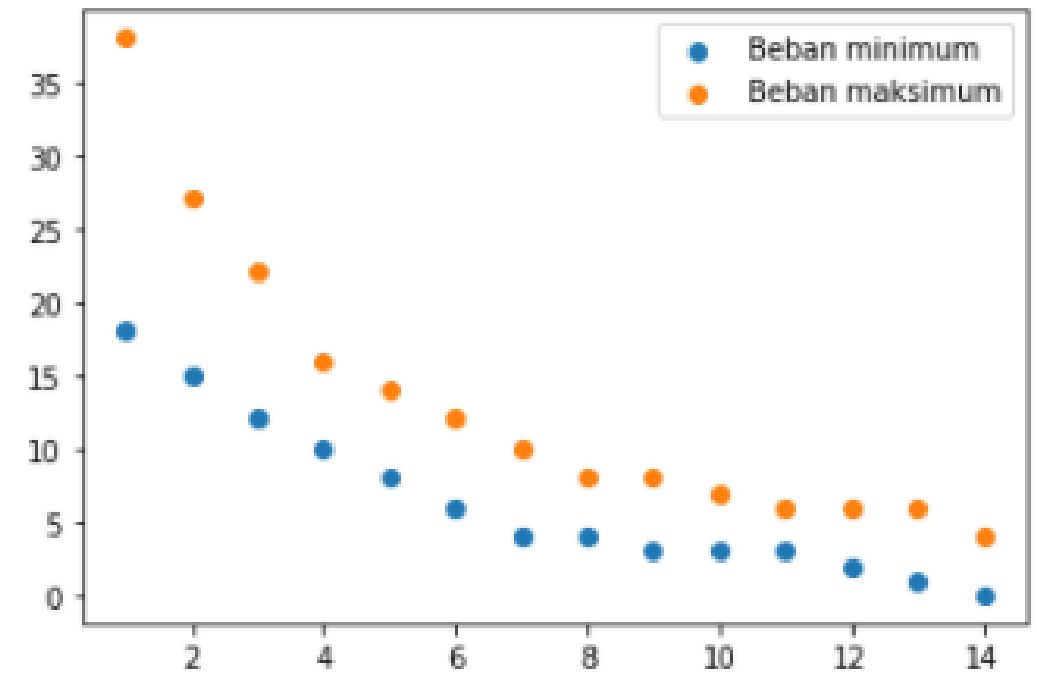

Sumber: Hasil Penelitian (2021)

Gambar 10. Scatter Plot Beban Maksimum Dan Minimum Populasi $=200$

Terlihat Scatter Plot pada Gambar 10 terlihat konsistensi jarak antara Beban Maksimum dan Beban Minimum mulai terlihat. Variasi mutasi gen menjadi semakin berkurang dikarenakan Mutasi Terbatas mulai mendapat sedikit pilihan.

Setelah itu Algoritma Genetika dijalankan dengan keturunan $=300$. Dan dihasilkan yang terlihat pada Tabel 11 yaitu iterasi minimal yang didapatkan adalah 10 iterasi dengan nilai minimum pergerakan kelas adalah $14.75 \%$.

Tabel 11. Hasil Algoritma Genetika populasi $=300$

\begin{tabular}{|c|c|c|}
\hline n_populasi & $\begin{array}{l}\text { Beban }=0 \text { setelah } \\
\text { Iterasi ke: }\end{array}$ & $\begin{array}{l}\text { nilai minimum } \\
\text { pergerakan kelas }\end{array}$ \\
\hline 300 & 10 & $6.6 \%$ \\
\hline
\end{tabular}

Sumber: Hasil Penelitian (2021)

Setelah itu Algoritma Genetika dijalankan dengan keturunan $=500$. Dan dihasilkan yang terlihat pada Tabel 12 yaitu iterasi minimal yang didapatkan adalah 10 iterasi dengan nilai minimum pergerakan kelas adalah $11.4 \%$. 
Tabel 12. Hasil Algoritma Genetika populasi $=500$

\begin{tabular}{|c|c|c|}
\hline n_populasi & $\begin{array}{l}\text { Beban }=0 \text { setelah } \\
\text { Iterasi ke: }\end{array}$ & $\begin{array}{l}\text { nilai minimum } \\
\text { pergerakan kelas }\end{array}$ \\
\hline 500 & 10 & $11.4 \%$ \\
\hline
\end{tabular}

Sumber: Hasil Penelitian (2021)

Nilai minimum pergerakan kelas tidak akan tercapai 100\% dikarenakan matakuliah praktek lebih banyak. Hal ini normal karena data yang diuji menggunakan program studi Teknik Mesin S1 yang terdapat banyak matakuliah di ruang Praktek. Namun dengan adanya ruang induk hasilnya adalah mahasiswa sudah memiliki ruang teori yang diprioritaskan.

Tabel 13. Rata-rata Hasil Percobaan

\begin{tabular}{lllll}
\hline \multirow{2}{*}{ n_populasi } & \multicolumn{2}{l}{$\begin{array}{l}\text { GA.Sequence-Dependent } \\
\text { Times Nilai beban }=0.00140\end{array}$} & $\begin{array}{l}\text { GA Mutasi Terbatas } \\
\text { Nilai beban }=0\end{array}$ \\
\cline { 2 - 5 } & Iterasi & $\begin{array}{l}\text { nilai pergerakan } \\
\text { kelas }(\%)\end{array}$ & Iterasi & $\begin{array}{l}\text { nilai pergerakan } \\
\text { kelas }(\%)\end{array}$ \\
\hline 100 & 22 & 8 & 12 & 20.3 \\
\hline 200 & 12 & 19.5 & 14 & 6.6 \\
\hline 300 & 9 & 14.6 & 10 & 6.6 \\
\hline 500 & 12 & 17.1 & 10 & 11.4 \\
\hline
\end{tabular}

Sumber: Hasil Penelitian (2021)

\section{Kesimpulan}

Berdasarkan hasil penelitian yang telah dilakukan, dapat diambil kesimpulan bahwa Algoritma Genetika dengan mutasi individu terbatas dapat membantu dalam pembuatan jadwal perkuliahan dengan hard constraint dan soft constraint secara proporsional. Pembatasan mutasi juga sangat diperlukan untuk menangani kasus constraint dengan penjadwalan perkuliahan yang memiliki kondisi pemilihan ruang, jam dan hari yang terbatasi. Pengujian dalam percobaan yang dilakukan terhadap data kurikulum untuk Semester Ganjil Tahun Akademik 2020/2021 dengan menggunakan Algoritma Genetika dengan Mutasi Terbatas yang menghasilkan beban minimum $=0$ dengan iterasi $=10$ dengan populasi sebanyak 500 . Kelemahan dari metode ini adalah adanya proses pengklasifikasian terhadap kelas dan untuk kasus yang lebih diinginkan keteracakan akan membutuhkan lebih banyak iterasi.

\section{Daftar Pustaka}

Abdelhalim, E. A., \& El Khayat, G. A. (2016). A Utilization-based Genetic Algorithm for Solving the University Timetabling Problem (UGA). Alexandria Engineering Journal, 55(2), 13951409. https://doi.org/10.1016/j.aej.2016.02.017

Ahmad, S. G., Munir, E. U., \& Nisar, W. (2012). PEGA: A Performance Effective Genetic Algorithm for task scheduling in heterogeneous systems. Proceedings of the 14th IEEE International Conference on High Performance Computing and Communications, HPCC2012 - 9th IEEE International Conference on Embedded Software and Systems, ICESS- 
2012, 1082-1087. https://doi.org/10.1109/HPCC.2012.158

Aristoteles, Wardiyanto, \& Dwiastuti, A. (2015). Evaluasi Kinerja Genetic Algorithm (GA) dengan Strategi Perbaikan Kromosom Studi Kasus: Knapsack Problem 1. Jurnal Komputasi, 3(2), 162-168.

Hijriana, N. (2015). PENERAPAN METODE ALGORITMA GENETIKA UNTUK PERMASALAHAN PENJADWALAN PERAWAT ( Nurse Schedulling Problem ). Info Teknik, 16(1), 61-74.

Myori, D. E., \& Hastuti, H. (2019). Kombinasi Logika Fuzzy dan Algoritma Genetika untuk Masalah Penjadwalan Perkuliahan. Seminar Nasional Teknik Elektro UIN Sunan Gunung Djati Bandung (SENTER 2018), 284-292. http://senter.ee.uinsgd.ac.id/repositori/index.php/prosiding/article/view/senter2018p31

Pinedo, M. L. (2008). Scheduling: Theory, algorithms, and systems. In Scheduling: Theory, Algorithms, and Systems. https://doi.org/10.1007/978-0-387-78935-4

Qashlim, A., \& Assiddiq, M. (2016). Penerapan Algoritma Genetika untuk Sistem Penjadawalan Kuliah. Jurnal IImiah IImu Komputer, 2(1), 1-6.

Shiau, D. F. (2011). A hybrid particle swarm optimization for a university course scheduling problem with flexible preferences. Expert Systems with Applications, 38(1), 235-248. https://doi.org/10.1016/j.eswa.2010.06.051

Zhang, G., Hu, Y., Sun, J., \& Zhang, W. (2020). An improved genetic algorithm for the flexible job shop scheduling problem with multiple time constraints. Swarm and Evolutionary Computation, 54(February), 100664. https://doi.org/10.1016/j.swevo.2020.100664 